\title{
A Defense of a Thomistic Concept of the Just Price
}

\author{
Daryl Koehn \\ University of St. Thomas, Minneapolis
}

Barry Wilbratte

University of St. Thomas, Houston

\begin{abstract}
Since St. Thomas Aquinas was one of the first scholastics to analyze the idea of a "just price," economists, economic historians and philosophers interested in the philosophical underpinnings of the market have focused on Aquinas's writings. One group insists that Aquinas defined the just price as the payment needed to cover sellers' labor and material costs. A second camp vehemently counters that Aquinas's just price is simply the going market price. We argue that neither of these views is correct. The Thomistic just price is the price that would be agreed to by a just person as part of an exchange. This "just person price" takes into account the well-being of the individual transactors and the good of the entire community. Such a price reduces neither to the cost-covering price nor to the market exchange price. A Thomistic concept of the just person price deserves to be reconsidered, especially because a Thomistic approach offers some useful ways to deal with issues quite differently from the popular neoclassical approach directed toward arriving at a socially optimal market price.
\end{abstract}

KEY WORDS: just price, exchange, neoclassical economics, Aquinas

$\mathrm{M}$ UCH INK HAS BEEN SPILLED regarding the medieval notion of the "just price." Since St. Thomas Aquinas was one of the first scholastics to write specifically about this issue, many economists and economic historians and a few philosophers have focused their attention on his view. ${ }^{1}$ The interpreters fall into two camps. The first group insists that Aquinas understands the just price as the price that recompenses the seller for the cost of his labor and materials. This price is seen as including a risk premium when producing an item is especially tricky; a time premium if the process occurs over a long period of time; or a wage premium if the process is time-consuming. ${ }^{2}$ We will refer to this view the "cost covering" notion of the just price. A second group vehemently counters that Aquinas conceives of the just price as the voluntarily agreed-to market price or what neoclassical liberal economists would term the "exchange price." We will call this view the "market exchange view."

This paper argues that neither of these understandings of Aquinas is correct. It is more accurate to say that a Thomistic just price is the price that would be agreed to 
by the just person as part of an exchange of goods and services. This "just person" exchange price takes into account the well-being of all who are parties to a given transaction and the good of the larger community. ${ }^{3}$ We will show that, since the just person price for an item may sometimes be higher or lower than a particular merchant's cost to produce that product, Aquinas does not equate the just price with the cost-covering price. $^{4}$

On the other hand, Aquinas does not think that each and every bargain struck between market transactors is, by definition, just. To give a brief preview of what we argue below: The price will not be fair in the eyes of a Thomist if the transaction involves intentional deceit; or if one of the parties tries to take too much for himself or herself and, as a result, substantially harms another's well-being, a common practice following natural disasters. There are a variety of other circumstances in which the just person price may be lower or higher than the going market or exchange price. In general, though, the prevailing market exchange price will be just if we take the market price to be a price that emerges as a collective evaluation of the worth of that product at that particular point in time as assessed by 1) reflective sellers who know their costs, who are attuned to their own and the buyers' well-being and who respect the dignity of all of their fellow human beings; and by 2) reflective buyers who grasp whether and to what the extent the product meets their needs and who, like the sellers, are sensitive to the common good (which includes fair individual voluntary transactions regularly occurring within the community).

The first part of the paper provides an overview of what we take to be a Thomistic understanding of what could be termed the "just person price." Before we begin, a caveat is in order. As other commentators have noted, Aquinas's theorizing consistently centers on the nature of being. Aquinas's thinking about other matters such as beauty, justice, virtue, charity, prices, etc., while largely internally consistent, appears scattered throughout his works. ${ }^{5}$ We have gathered various strands of Aquinas's argument as we develop his view of the just price using concrete examples and as we contrast that view with neoclassical economic views in order to highlight the distinctiveness and continuing practical merit of Aquinas's concept of the just person price. For purposes of illustration, we consider not only Aquinas's own examples but devise some of our own in order to clarify the just person price approach. It is perhaps most accurate, therefore, to say that we here offer a Thomistic interpretation of the just price.

Another important opening note: As employed in this paper, the term "neoclassical" refers to microeconomic analysis from the time of William Stanley Jevons ${ }^{6}$ and León Walras ${ }^{7}$ to the present day. (For the most part, modern microeconomics proceeds in the framework of neoclassical analysis.) In contrast to classical economists, who held several theories of value but whose predominant explanation of value evolved primarily into one based on the quantity of labor embodied in a product, neoclassical economists explain market price and value in terms of supply and demand. Neoclassicists see supply as deriving from the costs incurred by competitive firms and demand as based on consumer behavior in the context of utility maximization. In addition, neoclassicists as defined herein consider compensation of the factors of production to be integrally related to the market price of the final product. 
The second part of the paper refines our Thomistic notion of a just person price by showing how it can emerge through market transactions conducted among agents in a smaller community. The third part of the paper sketches several reasons why Aquinas's insight is worth preserving and still relevant to modern life.

\section{WHAT IS THE JUST PRICE? A THOMISTIC OVERVIEW}

Aquinas follows Plato and Aristotle in defining justice as a relation among persons: "Justice by its name implies equality, it denotes essentially a relation to another,

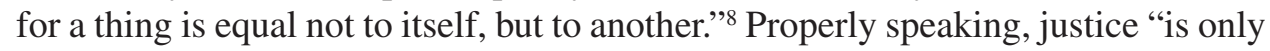
in one man towards another. . . . Justice is concerned about external things, not by making them, which pertains to art, but by using them in our dealings with other men." "Aquinas takes his lead from the ancients, defining justice as rendering to each person his or her due:

The matter of justice is an external operation in so far as either it or the thing we use by it is made proportionate to some other person to whom we are related by justice. Now each man's own is that which is due to him according to equality of proportion. Therefore the proper act of justice is nothing else than to render to each one his own. ... [J]ustice is first of all and more commonly exercised in voluntary interchanges of things, such as buying and selling, wherein those expressions are properly employed; and yet they are transferred to all other matters of justice. The same applies to the rendering to each one of what is his own. (italics ours) $)^{10}$

Aquinas never explicitly defines what he takes a just price to be. However, as noted above, one can draw inferences from his discussion of justice and from the numerous examples he provides of unjust pricing or bargaining. The above quotation suggests that a price will be ethically good and just insofar as both buyer and seller are voluntarily rendered that which is due to them or what is their "own." But what is due to a person? The simplest answer is: good order. Here Aquinas takes his lead from a key passage in Aristotle. Justice is the greatest and best of moral virtues because it is both rational and the source of intra-personal and communal order:

A virtue considered in its species may be greater or less, either simply or relatively. A virtue is said to be greater simply, whereby a greater rational good shines forth.... In this way justice is the most excellent of all the moral virtues, as being most akin to reason. This is made evident by considering its subject and its object: its subject, because this is the will, and the will is the rational appetite . . . : its object or matter, because it is about operations, whereby man is set in order not only in himself, but also in regard to another. Hence "justice is the most excellent of virtues." (italics ours) $)^{11}$

For Aquinas, justice is especially commendable, because, unlike liberality, this very rational virtue looks to the good of the whole:

If we speak of legal justice, it is evident that it stands foremost among all the moral virtues, for as much as the common good transcends the individual good of one person. In this sense [Aristotle] declares . . . that "the most excellent of the virtues would seem to be justice, and more glorious than either the evening or the morning star." But, even 
if we speak of particular justice, it excels the other moral virtues for two reasons. The first reason may be taken from the subject, because justice is in the more excellent part of the soul, viz., the rational appetite or will, whereas the other moral virtues are in the sensitive appetite, whereunto appertain the passions which are the matter of the other moral virtues. The second reason is taken from the object, because the other virtues are commendable in respect of the sole good of the virtuous person himself, whereas justice is praiseworthy in respect of the virtuous person being well disposed towards another, so that justice is somewhat the good of another person. ... Hence [Aristotle] says ... . "The greatest virtues must needs be those which are most profitable to other persons, because virtue is a faculty of doing good to others. For this reason the greatest honors are accorded the brave and the just, since bravery is useful to others in warfare, and justice is useful to others both in warfare and in time of peace." Although the liberal man gives of his own, yet he does so in so far as he takes into consideration the good of his own virtue, while the just man gives to another what is his, through consideration of the common good. Moreover justice is observed towards all, whereas liberality cannot extend to all. Again liberality which gives of a man's own is based on justice, whereby one renders to each man what is his. (italics ours) ${ }^{12}$

Justice, then, is the virtue of acting to promote the common good by using one's reason to determine and then to render to each person that which is due to him or her. This determination occurs within specific, highly contextual voluntary transactions and exchanges. For a Thomist, these transactions are the primary arena or field in which the virtue of justice is exercised and the common good (grounded in justice which is the common virtue par excellence) realized. The Aquinean quoted above bears repeating: "Justice is first of all and more commonly exercised in voluntary interchanges of things, such as buying and selling, wherein those expressions are properly employed." Aquinas's view, to use modern terms, is more communitarian than welfarist or utilitarian. One is not morally permitted to treat one or more persons unfairly in an exchange in order to achieve the greatest good of the greatest number of people. Each transactor has a claim to be rendered his or her due in each and every exchange. For the Thomist, the just person engaged in an interpersonal exchange seeks to be sensitive to these justified individual claims on the part of both buyer and seller to a host of goods, especially necessary material goods such as food and water.

Perceiving and determining the common good requires that we use our reason. Thus, the just price is the price that is acceptable to those individuals who reflect and deliberate with a view to finding the practical reason capable of guiding their action in the situation at hand. We would stress that the just price is always arrived at in light of a particular situation or transaction in which the agent is directly engaged. Aquinas implicitly follows Aristotle in making practical judgment begin and end with an informed perception of the case at hand. ${ }^{13}$

Practical reason looks for and identifies genuine goods capable of giving order and meaning to a human life lived in a community where particular practices and actions affect our fellow human beings for better or for worse. The good life requires that citizens render each other that which is due to them, and what is most due to people is the ability to live a decent, reasoned and ordered life. Therefore, a 
Thomistic just exchange price is the price consistent with transactors 1) being able to sustain biological, family, and public life (one cannot order one's life if one is dead; and being human means living with and loving others); and 2) being able to develop and use practical reason in daily life. The just price will be good in both of these respects for buyer and seller alike. Moreover, it is the just person who is the best judge of our natural needs and the correct value of goods:

All material things obey money, so far as the multitude of fools is concerned, who know no other than material goods, which can be obtained for money. But we should take our estimation of human goods not from the foolish but from the wise: just as it is for a person whose sense of taste is in good order, to judge whether a thing is palatable. (italics ours) $)^{14}$

The just price is the price to which a just buyer and just seller would commit as part of a voluntary exchange conducted with a reasoned awareness of each other's good and the good of the larger community. In other words, the just price is preeminently a "just person price."

From the above sketch, it should be clear that the Thomistic just person price ought not to be equated (as a matter of definition) with the market exchange price understood by neoclassical economists as the price at which sellers voluntarily offer some specific good and at which buyers voluntarily accept the offer and pay for this same good. In general, the participants in market demand will necessarily include the foolish, giving them a role in establishing the market price. Furthermore, the neoclassical market price will exclude marginalized community members whose resources are insufficient to afford them a place on the demand curve, thus preventing them from having a say in what the prevailing price should be. ${ }^{15}$

In addition, one can readily find specific conditions under which the market price diverges from a Thomistic just person price. For example, after hurricanes or other disasters, some sellers engage in so-called "price-gouging." Insofar as buyers are not forced to buy extremely high-priced gas from sellers-would-be buyers can refrain from purchasing gas completely or seek other sources-, neoclassical economists focused on non-coerced agreement will generally not find injustice in the price as long as buyers voluntarily opt to pay it. ${ }^{16}$ Indeed, neoclassicists may see social welfare benefits from allowing sellers to charge much higher prices after a disaster (e.g., more supplies will quickly flow into a hard-hit area as sellers try to capitalize on high demand for, say, gasoline). ${ }^{17}$ A Thomist, by contrast, would argue that price-gouging is not just for several reasons. First, in this day and age, most people need gasoline to make a living, earn money and buy food. In the absence of public transportation, citizens must rely upon private vehicles to obtain the necessities of life. If anything is due to individuals, it is the basic necessities. For Aquinas, anyone who out of greed sets the price so high that others cannot afford nutritious food or crucial supplies acts to deprive fellow citizens of what is their due and so acts unjustly. As Aquinas makes clear in the following quote, when individuals can readily and easily help others without harming themselves, they have an obligation to extend that help in and through the exchange transaction itself: 
If someone would be greatly helped by something belonging to someone else, and the seller not similarly harmed by losing it, the seller must not sell for a higher price: because the usefulness that goes to the buyer comes not from the seller, but from the buyer's needy condition. ${ }^{18}$

It is the purposeful and mindful meeting of legitimate needs of particular individuals with whom one is transacting that makes for a just exchange, not the exchange's voluntariness.

Second, price-gougers distort their own souls to the extent that they behave selfishly. They give no thought to the possible harm they inflict on those individuals with whom they transact and whom they could readily help by charging a price incorporating only normal profits. The "needy condition" of possibly desperate buyers seeking clean water, for example, does not enter into the thinking of price gougers. By acting in a self-absorbed and unjust way, price-gougers deprive themselves of the most excellent moral virtue and so fail to render that which is due to themselves as human beings. ${ }^{19}$ To put the same point slightly differently: an unreasonably and abnormally high price set by the price-gouger cannot be the just price for "the just price [is, for Aquinas] simply the price that the . . . just person determines." ${ }^{20}$ When a selfish person fails to exercise her reason carefully and virtuously in setting the price and instead merely follows her greedy appetite for more, she does not set the price as a just, deliberate, reflective person would determine it. In Aquinas's eyes, gain for the sake of gain is immoral. ${ }^{21}$ Therefore, the price cannot be essentially just, even if, in the rare case, the price asked by a greedy seller accidentally coincides with the just price as established by a virtuous person who has subjected her emotions to the dictates of reason and thereby ordered her soul. When our passions and our tendency toward simple opportunism are not so controlled, then our actions begin to look arbitrary. A gouging price is not tied to labor costs, seller risk, or product quality. Often sellers are merely exploiting a sudden restriction of supply and/or surge in demand, such as occurs after a natural disaster.

It may be objected that a price does not "gouge" simply because it is set high by a seller. Aquinas concedes as much. As the above quote explicitly indicates, Aquinas does not think that sellers have any ethical obligation to sell below cost if, by doing so, they would greatly harm themselves. We would argue that a price involves gouging only if it exceeds the legitimate costs incurred in supplying the good or service. However, care must be taken to specify which costs are legitimate. To distinguish between gouging and merely charging a high price, we would distinguish two types of costs, above which the price amounts to gouging. The first are the "monetary costs," such as those a gas station owner might incur in purchasing gasoline for resale to consumers in the wake of a disaster. Monetary costs would include extraordinary expenses such as those involved in transporting fuel from a distant refinery as well as standard expenses (e.g., the replacement cost of the equipment employed, the value of the seller's time and a competitive return on investment, which includes a normal profit). Merely charging a higher than usual price does not constitute price gouging under these conditions, when the seller's own monetary costs are unusually high. 
To the monetary costs, we would add what might be termed "subjective costs." As enumerated in part by Zwolinski, ${ }^{22}$ these subjective costs include factors such as risk, discomfort, and physical effort. If the station owner travels over damaged highways or through a populace angered and desperate in the wake of the disaster, he incurs risks that other potential suppliers are unwilling to take (as revealed by his action and their inaction). The intrepid seller may thus justly claim compensation in the form of a higher than usual price for running these risks. Similarly, if a seller travels a long distance with little rest or at inconvenient times, he may reasonably expect compensation for the unusual discomfort involved. Thomistic and neoclassical economists, in principle, agree on the justice of these sorts of premiums (although a Thomist would think that just sellers might refrain entirely from demanding compensation for his sacrifice if potential buyers are desperate).

We, then, would define price-gouging (roughly) as the practice of sellers charging a price higher than required to recoup normal plus extraordinary monetary costs and any subjective costs that would be deemed reasonable by practically wise and virtuous buyers who are contemplating transacting with these sellers. So understood, a gouging exchange price (even when voluntarily agreed to by a purchaser) is not, from a Thomistic perspective, just. Consequently, pace those who impute a market exchange view to Aquinas, one may not conclude that the just price is always equal to the prevailing market exchange price.

[Note that gouging may occur even if the seller's price corresponds to that commonly set by other sellers in the community. After a natural disaster, sellers may collectively take advantage of buyers' panic or lack of information regarding supplies coming online under conditions in which the flow of information is impeded. In addition, elimination of some suppliers may leave surviving sellers with the power to set prices above competitive levels. Finally, as we argued previously, the market price will not serve the needs of the community equally to the extent that it serves only those able to pay and excludes the poor. ${ }^{23}$ In that case, not every one is rendered his or her due. On the other hand, Aquinas would, we believe, readily concur that the market may function as an objective check in establishing the costcovering price as defined above. Self-serving tendencies may tempt sellers to inflate their subjective costs and to rationalize charging a price that informed and more virtuous members of the community would consider excessive. From a Thomistic perspective, the market price set by other sellers acting justly may moderate the behavior of narrowly self-interested merchants or sellers who have lost perspective.]

It is easy to come up with other examples in which the just price should not be equated with the neoclassical exchange price. Let us suppose that a buyer and seller voluntarily consummate a deal at a price of $\$ 1,000$, but that deal results in ecological harm to many other people. According to the interpretation of the just price sketched above, $\$ 1,000$ cannot be a just price, even though it is a voluntary exchange price. A just buyer and seller would have taken into account what economists now call "negative externalities" when considering what the price for the proposed transaction ought to be. In general, a negative externality is an uncompensated cost imposed on persons who are not parties to the economic activity generating the cost. An obvious example is the spillover cost arising from pollution. Absent community 
action of some type, sellers often will not take such costs into consideration at all, let alone compensate affected external parties. Since the just price presupposes the continued existence of the community, a transaction that would substantially harm the well-being of one or both transactors and/or others within the community may have no just price. (Recall from our opening discussion that, for Aquinas, a just person is always heavily other-focused and thus attentive to the needs of fellow members of the community as well as her own.) Or the just price might need to be set high enough to compensate for the costs imposed on others, a point discussed later in this paper.

The just person price, then, is not identical with a market exchange price, which may deviate from the just price for a number of reasons. On the other hand, the just price is not an invariable one-size-fits-all, cost-covering price that every seller of a particular product somehow deserves to receive. It is true that those in the trades and crafts have, Aquinas thinks, a moral right to recoup their outlays. If the price does not cover their costs, the arts and crafts needed by a community will disappear. ${ }^{24}$ Loss of needed trades would damage the communal good and, therefore, would not be just. But Aquinas does not argue that there is a single just price owed to each person in the same trade. He believes that the just person price will vary among sellers in accordance with the circumstances of each. It will reflect the time and risk involved in producing the good, product scarcity, and other such factors:

[T]he just price of things is not fixed with mathematical precision, but depends on a kind of estimate, so that a slight addition or subtraction would not seem to destroy the equality of justice. ${ }^{25}$

[The seller] may lawfully [sell at a profit] either because he has bettered the thing, or because the value of the thing has changed with the change of place or time, or on account of the danger he incurs in transferring the thing from one place to another, or again in having it carried by another. ${ }^{26}$

We do not read Aquinas's list of factors as exhaustive but rather as illustrative of his larger point that sellers may legitimately and fairly charge for a variety of things they have done as part of providing a service or good to individuals in the community. The just person price would presumably reflect production time and efficiencies as well. A Thomistic reading would permit a wine producer to charge more for wine that takes six years to produce than for drink maturing in two years. A practically wise, reflective buyer will understand this production constraint and will willingly and freely compensate the vintner for this additional maturation time. In some cases, the just person price may be lower than the costs of some particular seller. Let us suppose that a second producer develops a more efficient system capable of producing the first wine in four, rather than six, years. From an Aquinean moral point of view, this more efficient producer may legitimately undercut the first producer's price. Although the lower price may no longer adequately cover the inefficient producer's costs, it nevertheless remains just. The wine, which is good for the health of citizens when drunk in moderation (and is needed by the Church for communion), remains available to consumers even after the price has been cut. 
Indeed, wine, a genuine good, becomes even more widely available to consumercitizens at this lower price.

The first vintner is free to improve his processes to make wine production at his facility more efficient. Or he may offer a different wine if he feels that a switch in product line would give him a competitive advantage. The first seller is not unjustly harmed by the mere fact of competition, because to participate in a market economy entails having to discover new ways to offer products and services on terms buyers find attractive. Aquinas does not condemn the market for encouraging innovation but rather praises the market as the mechanism for making the goods of life widely available.

What would a Thomist say about a case where a seller is going out of business and is forced to liquidate her inventory? If the seller offers the inventory at a below-cost price, are the buyers who purchase the discounted goods acting unjustly? Neoclassical economists would say "no." In their view, the market provides blessings by operating efficiently under conditions of competition and by rewarding the suppliers of resources in accord with the market value of the resources they provide. Sellers who cannot sell their inventory at a price low enough to entice buyers while still covering costs and generating a profit have, from a neoclassical perspective, no moral right to produce or sell that particular good. More efficient producers drive less efficient ones out of the market and benefit society by doing so.

An Aquinean answer would be more humane. Although no one has a moral right to be completely immune to market forces or to produce and retail inefficiently, the seller qua human being has, as it were, a human right to continue to live a decent life. A just buyer would not bargain or press the already stressed seller to lower his prices more. On the contrary, a just buyer might consider paying more than the requested price in order to help the seller earn enough money to start another business or to sustain herself as she prepares to transition to an occupation in which her skills are useful and thus in demand. Distressed sellers are members of the community and, as such, deserve to have their basic needs met. Here is a case in which one transactor can easily and readily help another individual in a direct way through the exchange itself at no great cost or harm to himself. As Aquinas repeatedly stresses, we should love our neighbors "out of charity . . . because they are nigh to us, both as to the natural image of God, and as to the capacity for glory." 27

Aquinas's primary focus in his discussions of the just price is on transacting fairly in face to face exchanges. In such exchanges, one is truly in the presence of those who are nearby or "nigh"-i.e., one is in the presence of one's "neighbors." Gains made in neighborly exchanges are ethically good only to the extent that they are used charitably and justly to promote the well-being of one's self and of others with whom one interacts in a direct and immediate way. A just person who profits from fair exchanges will also consider other ways in which to help her neighbors, especially those who may be lacking in basic needs: "[There] is no reason why gain [from trading] may not be directed to some necessary or even honorable end; and so trading will be rendered lawful; as when a man uses moderate gains acquired in trade for the support of his household, or even to help the needy" (italics ours). ${ }^{28}$ 
That said, we could find no indication in any of Aquinas's major works that he would think that the tradeswoman liquidating her inventory of socks has a moral right always to be a seller of socks. Perhaps the producer in this case has failed at her trade because she is not very good at it. Maybe she needs to find another trade. Aquinas understands that our conditions often change. People continually become richer or poorer, move up or down in rank. No status trait belongs essentially to any human being's state precisely because these dimensions of our existence can and do change: "Consequently matters which easily change and are extrinsic to them do not constitute a state among men, for instance that a man be rich or poor, of high or low rank, and so forth." ${ }^{29}$ We have a moral right not to starve or to be forced to live on the streets when neighbors are around who could help us, but we have no moral right to do a particular job or maintain a certain status. Nor do we have a moral right to demand or expect that our fellow citizens will reward us for taking bad risks or producing incompetently.

\section{THE RELATION BETWEEN THE JUST PERSON PRICE AND THE MARKET PRICE}

Where, one might ask, is the larger market in all of this discussion of the just person price? Does the market play any role in setting the just person price? Although the just person price is not the same as the neoclassical exchange price, Aquinas is aware that the just person price under certain conditions resembles, but is not always equal to, the exchange price insofar as both vary with conditions of supply and demand. It is not correct, therefore, to argue the "just price is a nebulous concept invented by pious monks who knew nothing of business or economics and were blissfully unaware of market mechanisms" and who did their best "to propagate the notion that the just price, instead of being set by the allegedly blind and unconscionable forces of the market, was determined by criteria of fairness without regard to the elements of supply and demand." ${ }^{30}$ A Thomistic interpretation of fairness is consistent with imputing to the market some degree of intelligence, especially if one assumes sufficient time for buyers and sellers to assess the costs and value of the product in question. Unlike the period immediately following a change in market conditions, when information regarding the new conditions has yet to reach all buyers and sellers, the market in the longer term typically both reflects and signals what buyers are willing and able to pay and what sellers need to recoup to cover their costs and to continue producing goods and services. In his arguments for private property, Aquinas contends that private property is good precisely because those who own the property are generally better stewards of property than the public in general. ${ }^{31}$ By analogy, consumers should be permitted to spend their money-property as they see fit; sellers should be allowed to devote their labor-property as they see fit. On a Thomistic interpretation, individual buyers and sellers intimately know their situations and are better custodians of the value of their property than anyone else could be. By signaling the value that citizens place on their money and labor, the market enables fair exchange to occur. 
Still, the market can run amok and is prone to manipulation and distortion. It is crucial to note that, in the above example of the two vintners, the second, more efficient producer did not intend to harm or destroy the first. If the second vintner were to drive prices very low with a view to eliminating rival wine producers, then the lower price would not, in Aquinas's eyes, be just. Wine producers, like everyone else, have basic natural needs and thus have a moral right to be allowed to participate in the economy of exchange to satisfy these needs. To impose undue hardship intentionally on one's rivals is vicious. The truly just person would never wish to destroy or capriciously impair the value of the productive resources of others who, along with him or her, constitute the community. For justice is a political virtue that presupposes community. A price or practice that eliminates the very community that grounds the idea of justice cannot possibly be fair.

For Aquinas, the pursuit of natural wealth (i.e., the goods or money required to meet basic human needs) is morally acceptable. The unreasonable, unchecked pursuit of money or "artificial wealth" is not. ${ }^{32}$ Medieval philosophers knew about and universally condemned those who engaged in price-gouging or who attempted to establish monopolies and to reap abnormal profits. ${ }^{33}$ While a market-oriented economist like Joseph Schumpeter views abnormal profits merely as an incentive for producers to increase output of the product in question or to engage in innovation $^{34}$, Aquinas and his scholastic peers see abnormally high profits as symptomatic of morally unjust greed or hubristic over-reaching.

Today we think of the market as a system of exchange between autonomous agents who most probably will never meet in person. When Aquinas refers to the "just price," he means the price mutually reached by reflective, considerate people who are transacting directly with each other, who are active in the same community, and who understand themselves as parts of one whole. Medieval communities were relatively small, and buyers and sellers typically would have known each other. In many cases, transactors were literally neighbors. Moreover, most buyers were simultaneously sellers. The shoemaker would acquire wheat by producing and selling shoes to the farmer who would grow and sell wheat to buy shoes. Most residents of a medieval town would have been aware of the status of almost everyone in that community.

Indeed, Rudolf Kaulla, R. H. Tawney, Max Weber, Heinrich von Langenstein, and others have argued that the just price reflects the status each community accorded various producers. ${ }^{35}$ On their view, the just price is the price needed to cover the producer's labor and expenses to maintain his or her station in life. Some scholars contend that the just price was the price set by guild producers in accordance with their sense of their relative importance or status in the community. But, as Roover has persuasively documented, the guilds set relatively few prices and often were viewed with suspicion if they attempted to fix a set price. ${ }^{36}$ In most cases, townspeople looked to the market to establish prices. ${ }^{37}$ For his part, Aquinas never refers to guilds or groups of producers as the arbiters of the just price. We have already shown that the just price should not be equated with the cost-covering price and that Aquinas did not believe that citizens had a moral right to a fixed status or a right to continue to practice some specific trade or craft. Nevertheless, these scholars' construal of the just price as status-based has the merit of reminding us that Aquinas's community 
was hierarchically ordered. Aquinas's thinking not only orders the individual soul in accordance with reason but also structures communities so that those with the most developed reason are in the best position to use that reason to promote the common good. So it is not far-fetched to argue that the just person price will in some way reflect and sustain the correct ordering of the community. Aquinas seems to envision that the just price emerges through market exchange among just (or potentially just) citizens who know each other's situation. How, then, does the market yield a just price consistent with a well-ordered soul and well-ordered community?

Aquinas does not offer a full-fledged theory of the market allocation of goods and services. However, in our view, a Thomist could still appeal to the market as a partial determinant of the just price. We must remember that most transactions in Aquinas's world were not "one-off" deals among strangers. Denizens of market towns regularly bought and sold bread, shoes, chairs, etc. Buyers could readily learn from fellow consumers what their peers were paying for goods and services and could then compare those prices with other sellers' asking prices. Pricing information would have traveled fast in a small, tightly-knit market town. Furthermore, insofar as they knew the sellers, buyers would have had some relatively accurate sense of what it costs a seller to bake bread or to stitch shoes. Buyers would have been able and willing to bargain on the basis of that knowledge. In the case of a frequently traded staple good (as opposed to a specialty item for which buyer or seller would have a unique need), sellers, too, would easily have acquired some sense of the going rate for the goods they wished to proffer. They would have known that there was little point in pricing their bread a few cents higher than what other bakers in the same town were charging. Both buyers and sellers would have arrived at a sort of common estimate of the value of the goods. ${ }^{38}$ This common estimate of social value would be based on "labor, cost of materials, risk, and carriage charges." ${ }^{39}$ If someone tried to corner the market or to price-gouge, the community very likely would have applied regulations or used communal shaming practices to curtail such practices. As Aquinas notes, no community can exist without sanctions against grievous vices such as murder or theft, and deceitful or injurious market exchanges are, for Aquinas, a type of theft. ${ }^{40}$

This common estimate would have reflected social values, including the value the community placed on supporting diverse trades. Different people have different jobs. Aquinas sanctions such diversity because it makes for the efficient production of a variety of genuine goods needed by the community:

Of all things that man makes use of, the chief are other men. Man is naturally a social animal, needing many things that the individual cannot procure by himself. The divine law therefore must needs instruct man to live according to the order of reason in his relations with other men. ${ }^{41}$

Several things are requisite for the good of a human society: and a number of things are done better and quicker by a number of persons than by one. . . ${ }^{42}$

Just as one man has various members which he functions in various capacities, all ordered to supply any need, since all functions cannot be supplied by one member, so the eye 
sees for the whole body and the foot carries the whole body. Likewise, in what pertains to all mankind, one man is not able to do all the things which are needed in a society, and, accordingly, different people properly work at different tasks. ${ }^{43}$

This array of tasks stems from both the diverse needs of the community and the different inclinations various men and women have toward particular forms of activity. ${ }^{44}$

Each group's members must earn enough through voluntary exchange to make a living in their specific form of employment. The division of labor and resultant benefits would be diminished if the common estimate of products' value did not enable a variety of trades and crafts to continue to exist. Therefore, the just person price will be set to encourage mutually beneficial transactions. In other words, fair transactions will be those that are sufficiently lucrative to enable trades people to continue in their trades (as long as they are willing and able to keep refining their trade and becoming more efficient in their craft with a view to meeting sustained consumer demand). While a single person has no moral right to be a seller of shoes forever, the community arguably does have a moral right to the continued existence of necessary trades (e.g., shoemaking, baking). If so, then the commonwealth may justifiably act to establish and preserve sub-communities and trades (and, even, in times of war, famine or emergency to set prices) since the communal authority has the right and duty "to procure by itself a sufficiency of goods for human life."45

The just person price, while covering labor and expense, will not be a numerically equal, one-to-one trade of good A for good B but will reflect transactors' assessment of the relative value of various goods. That assessment is based on the perceived necessity and utility of that which is being exchanged:

This one thing which measures all others things is . . . the need which embraced all exchangeable goods insofar as all things are referred to human needs. For things are not valued according to the dignity of their natures, otherwise a mouse which is a sentient thing would have a higher price than pearl which is an inanimate thing. . . If men had no needs, there would be no exchange. ${ }^{46}$

Thus, although tanners and farmers must both cover their costs

insofar as the farmer, whose function is the provision of food, is more necessary than the tanner whose function is the provision of shoes, by that amount in numerical proportion must the work of the tanner exceed that of the farmer so that many [less necessary] shoes are exchanged for one measure of [the more valuable] grain. ${ }^{47}$

In this respect, "the social calculus [of hierarchically ordered more or less desirable goods] must take priority over absolute occupational costs, for otherwise the presumed scale of balanced output would be distorted to the advantage of particular groups; and, [as Aquinas observes] 'if this reciprocity is absent . . . men are no longer able to dwell together."'48

Again, it is useful to compare a Thomistic approach with neoclassical economists' thinking. Aquinas might be said to be focused on the total or simple value of a good such as food or shoes. Total or simple value for Aquinas would mean something like the relative intrinsic value to transactors of a humanly necessary good produced and 
consumed within a close community. Neoclassicists, by contrast, when discussing product demand, focus on marginal utility (more precisely, on the marginal rate of substitution). The distinction between total utility and marginal utility was a fundamental contribution of neoclassical economists, making it possible for the first time to explain the market value of a commodity in terms of its use value. ${ }^{49}$ Neoclassicists interpret the total utility of a commodity as the sum of the benefit of all units of that commodity consumed by a household. In contrast, the marginal utility is the benefit yielded by a single unit of any desired product. Neoclassicists focus on the marginal utility of the last unit consumed.

Thus, if a household consumes 1,000 gallons of water per month, the total utility is the benefit yielded by all 1,000 gallons. Since this benefit includes the water used for such necessities as drinking and cooking, the total utility of the water is enormous. On the other hand, the marginal utility of the thousandth gallon consumed is very low. So although, if a household were faced with an all-or-none decision (the possible loss of the total utility of water), the household would pay a great deal to continue consuming water, it would pay very little to avoid being deprived of the thousandth gallon of water (the possible loss of the marginal utility of the thousandth gallon). Given that consumer decisions typically involve paying to consume a little more or a little less of a good (i.e., given that most consumer decisions involve the marginal units of the commodity consumed), the price a household is willing to pay for water is very low, reflecting the low marginal utility of the last units of water consumed. ${ }^{50}$

Using such reasoning (in actuality, a more rigorous and complete version of this reasoning involving indifference curves), a neoclassical economist will conclude that it is the marginal value of the last unit consumed that reflects the true value to society of producing an additional unit of the product in question. Therefore, it is entirely possible that the farmer's produce, although of greater use value in total, may command a lower price than the tanner's shoes if the marginal utility of the last unit of shoes consumed exceeds that of the last unit of food consumed. In the neoclassicists' eyes, the rational consumer should not feel cheated paying more for the shoes. For the neoclassicists, marginal utility and not total utility, in combination with marginal cost, plays the key role in ensuring that society's resources are used most efficiently, thereby maximizing the use value of resources available to all members of the community. ${ }^{51}$

To recapitulate: The Thomistic just price as determined by the just person reflects not social status but rather the social reality that some goods are needed for communal human life and, hence, are more valuable to transactors than other goods. This relative worth of goods is not lost on the common man. People know that they can live without shoes but must have food. If the common estimation reflects this valuation - and in an economy closely tied to basic needs, Aquinas believes that any common estimate will reflect this hierarchy of goods_-, buyers and sellers will act in accordance with practical reason, behaving as rational and careful stewards of their money and labor. Under these circumstances, the market price will in the long run more or less coincide with the just person price as long as 1) no coercion, deceit, or market manipulation is involved; and 2) externalities are inconsequential or are factored into the price. The price is just, though, not because it has been voluntarily 
agreed to but because the price has been established in accordance with practical reason and thus renders to each party that good which is truly due to him or her.

\section{THE MERITS OF A THOMISTIC APPROACH}

Like the neoclassicists, Aquinas is sensitive to the need for accurate information. The common estimate cannot emerge if information cannot flow reliably and quickly. And, like the neoclassicists, Aquinas understands that individual consumers and producers will generally know their needs, wants, and costs far better than a third party or remote authority. He wisely relies on the market of potentially and actually just persons to arrive at a common estimate of the mutually acceptable price.

It would be a mistake, though, to see Aquinas as a proto-neoclassical economist. Neoclassicists are primarily interested in promoting efficient production with a view to maximizing the satisfaction of consumer desires. Aquinas, however, is first and foremost interested in equity. No income distribution, no matter how efficiently attained, would qualify as just in the fullest sense unless each and every member of the community had his or her basic needs met through fair exchanges and through acts of outright charity. For a Thomist, the meeting of needs, not desire satisfaction per se, is the sine qua non of a just distribution of income and/or goods.

Given that within disciplines such as finance and strategic management, some theorists are moving away from approaches narrowly focused on shareholder wealth maximization, a Thomistic approach to a just price provides an insightful way to conceptualize price in this new context. A Thomistic equity-centered theory of a just person price can, in principle, be extended to deal with externalities such as pollution. Virtuous buyers and sellers simply would not agree to a price that did not factor in costs to themselves and to their neighbors. Peer pressure within the community and local legislation could be brought to bear by just citizens to insure that transactors do not ignore these costs. In cases where externalities are significant, just persons would act in ways that would keep socially costly products from entering the market in the first place or from being sold at prices that significantly understate the true costs associated with these products and thereby result in a greater output than is socially optimal. A Thomist can even argue that, through town hall meetings, just persons might be able to devise solutions to externalities relatively quickly by educating fellow consumers who, in the interest of justice, might then refuse to buy apparently cheap goods the production of which generated negative externalities exceeding the benefits of such goods or by dissuading suppliers from producing such goods.

By contrast, neoclassical solutions, conceived in terms of a broader and less neighborly market, emphasize market-based approaches such as taxes on externalities and cap-and-trade systems (supplemented by regulations to deal with special cases such as emergencies during which market responses to market-based measures would be too slow). This neoclassical approach requires that policy makers come up with necessarily imprecise estimates of market reactions (e.g., how much the price will rise and quantity will fall in response to a given pollution tax). While we are not so naive as to contend that a Thomistic reliance on just person pricing will 
work in every case, we would argue that this alternative approach to dealing with externalities is, in certain cases, a potentially effective alternative to the neoclassical approach. A Thomistic approach has the merit of reminding us that, when transactors themselves seek to be as just as possible, many problems can be nipped in the bud.

Moreover, Aquinas's just person, unlike some early neoclassical economists, readily accepts that market distortions such as barriers to entry and pricing power are possible. The just person understands that communal controls (e.g., rules, public shaming) may be necessary to correct for market distortions. An essential difference between Aquinas and modern neoclassical theorists' policy prescriptions for dealing with market distortions (e.g., antitrust laws; enhancement of competition) is that, whereas Aquinas envisioned solutions involving the collective subjective wisdom of virtuous citizens, neoclassical economists turn to more mechanistic approaches with experts advising officials of a standing government on how best to deal with extensive markets consisting of numerous buyers and sellers.

Sellers seeking to charge an equitable price are likely to find that the Thomistic just person price concept provides better practical guidance than that given by a pricing law promulgated in the wake of a natural disaster. We take seriously Zwolinski's dual contention that 1) merchants may be unable to reach a clear understanding of what any such pricing law requires of them; and 2) legal prohibitions can create disincentives for sellers to engage in economic activities that provide necessities to the most vulnerable. ${ }^{52}$ The just person price is helpful here because a conscientious seller who desires to charge a just price will have the best knowledge of her costs, monetary and subjective. Rather than merely complying with an abstract, onesize-fits-all legislated rule, a just seller will use her knowledge (supplemented with feedback from the larger community) to arrive at a fair price. Anti-gouging laws are generally enacted not to deal with the specific emergency at hand but to establish a framework for a series of emergencies with differing conditions and costs. The just seller, better able to identify the costs attendant upon conditions on the ground and to assess her potential for adapting to these costs, may have a significant advantage over both well-intentioned legislators and rule-compliant merchants when it comes to identifying a fair price that best serves the needs of the community.

Aquinas's focus on the legitimate moral claims of each and every individual results in a pricing theory attuned to the needs of the more marginal members of the community. Some modern defenders of the free market forget that the exchange price will never be just as long as some citizens lack money and so cannot vote their preferences with their dollars. The preferences of those without funds never appear on the demand curve. They do not participate in the setting of a price for housing or health care. For Aquinas, the just person price for necessary goods will be zero in some cases. The monks had a moral obligation to feed and clothe the abject poor at no cost because each person has a moral, natural right to live:

$[\mathrm{M}]$ an ought to possess external things, not as his own, but as common, so that, to wit, he is ready to communicate them to others in their need... Things which are of human right cannot derogate from natural right or Divine right. Now according to the natural order established by Divine Providence, inferior things are ordained for the purpose of succoring 
man's needs by their means. Wherefore the division and appropriation of things, which are based on human law, do not preclude the fact that man's needs have to be remedied by means of these very things. Hence whatever certain people have in superabundance is due, by natural law, to the purpose of succoring the poor. ${ }^{53}$

Reflective people understand that this right to life imposes a correlative duty on the community to make provision for those who cannot adequately feed or clothe themselves. During the Middle Ages, this duty was voluntarily assumed by those monks who strove to bring good order to their souls and their community. The monks charged the rich citizens with the duty of helping to pay for the care of the poor. The concept of the just person price, unlike the exchange price of neoclassical economics, recognizes this duty to the poor and brings this duty, so to speak, into market exchange itself. ${ }^{54}$ Buyers and sellers, be they rich or poor, are obligated to try to meet each other's needs through exchange by establishing a just person price. Hence, a Thomist would not have any problems with a just seller of bread charging a destitute buyer less than a prosperous one.

A Thomist is able to develop a sophisticated moral market approach and at the same time to avoid falling into the naïve or wishful thinking so evident among some so-called "social justice" proponents. Aquinas thinks we are all subject to delusion. He views the market as a kind of objective check on wishful thinking. ${ }^{55}$ We have already argued that Aquinas allows for innovation in production methods. While some sellers may wish for an eternally stable price, Thomists would have no problem with sellers inventing ways to lower prices-as long as these same sellers do not intentionally set out to eliminate competition. Lowering prices, especially on basic goods, typically serves the interest of the whole the community by making such goods more affordable to the poor as well as to those who are relatively more wealthy.

Furthermore, like Aristotle, Aquinas is conscious of the problem of buyers' remorse. The price at which a deal is struck does not become unjust merely because the buyer later comes to regret the purchase and wishes she could "buy for a song and sell at a premium.." ${ }^{\prime 6}$ If relevant features of the product are truthfully represented at the time of the sale, the buyer knows what she is buying. Prior to making a purchase, a buyer can learn the price at which others are selling this good. If the buyer later thinks she paid too much, then she failed to be a good steward of her own property. In Aquinas's eyes, that failure is the buyer's, not the seller's.

Note, too, that Aquinas places no general moral obligation on the seller to tell the buyer whether, when, or where a better price may be in the offing. Aquinas takes up the following intriguing case: If a merchant bringing wheat to a market town knows that more wheat is due to arrive shortly and likely will drive the market price down, may the merchant justly sell his wheat at the prevailing price, or must he publicly announce that more wheat is on the way? Aquinas answers that the merchant may justly sell the wheat at the common estimate of its value at the point at which the merchant arrives in town (i.e., at the higher price). But the merchant would act even more virtuously if he were to lower the price at which he was willing to sell his wheat. ${ }^{57}$ This nuanced answer is entirely consistent with Aquinas's just person price 
approach. Insofar as the merchant sells his wheat at the common estimate, which typically will cover the merchant's expenses and will reflect the value that others in the town have been willing to pay in the past to get this necessary foodstuff, the merchant acts justly. His action in no way undermines personal or communal order. However, because the common good would be advanced even more if wheat were to become cheaper and thus more readily available to all individuals within the community who need bread to survive, the merchant who can lower his price without substantially harming himself shows himself to be more committed to virtue.

Nevertheless, it is significant that Aquinas does not make it morally incumbent on the merchant to gather and share all potentially relevant market information with buyers. We would suggest that he refrains from going that far for three reasons. First, buyers have a moral duty to inform themselves of market supply and demand conditions. Aquinas contends that we all need to be stewards of our personal well-being. Second, if merchants had a moral duty to inform buyers about any and all possible changes in market conditions, these sellers would incur an expense connected with information-gathering. That cost would need to be reflected in the just person price and would drive up the costs of many basic necessities, thereby harming those who are already struggling to buy food, water, shelter, etc. Third, the merchant in question has done nothing wrong. It has merely happened that, by chance, he has arrived ahead of the other wheat merchants. In general, the just price must be determined not by chance but by objective features such as costs, quality, quantity, seller risk, rarity, buyer neediness, etc. If Aquinas were to base the just price on arbitrary or chance facts likely to affect the future market value of the good, the price would cease to be within the ken of the reason of the just person and so would lose the very intelligibility that is the basis of its fairness.

A party to a transaction has a moral obligation to disclose information about the product only when the party knows some objective feature of the product that is likely to cause the perceived value or utility of this item to differ from its actual value. Withholding such information would border on deception. During price negotiations, a seller must disclose the truth about the quality or quantity of the good he is selling. After all, buyers will want to know such information when deciding how fit the product is to meet their needs. Conversely, a buyer who knows that a book is worth far more than the seller is asking-for example, the buyer knows the objective fact that the book is extremely rare-should offer the seller more. ${ }^{58}$ To pay the seller the low asking price would in that case be wicked, a point Aquinas illustrates by using this book example first given by St. Augustine:

As Augustine says ..., "men are inclined to wish to buy for a song and sell at a premium. But since in reality this is wicked, it is in every man's power to acquire that justice whereby he may resist and overcome this inclination." And then [Augustine] gives the example of a man who gave the just price for a book to a man who through ignorance asked a low price for it. Hence it is evident that this common desire is not from nature but from vice, wherefore it is common to many who walk along the broad road of $\sin .{ }^{59}$

Aquinas's theory of the moral market allows for individual variation in transactions. Although the Thomistic market price-if it reflects a common estimate of 
the value of a product or service, a value that realizes the shared good of buyer and seller alike and does not harm the common good-will qualify as the just person price, there may nonetheless be at any moment individual contract prices somewhat higher or lower than this common estimate. ${ }^{60}$ These individual transaction prices will reflect the needs, desires, and the advantages and disadvantages of individual buyers and sellers. Are these prices unjust because they do not conform exactly to the going market price or common estimate? Not necessarily. Aquinas gives the example of an exchange between a buyer who really needs a particular item and a seller who equally needs this thing and is understandably reluctant to part with it. In this case, the seller may justly demand a price that is higher than the cost to produce the item or even higher than the market-based replacement cost. Why? In this case, the lack of the good would impose an equal burden on seller and buyer. Both equally need the good in question. The seller may justly ask for what might be construed as a premium or payment for treating himself unjustly; and a just buyer would appreciate and honor the seller's perspective. In giving up that which he needs, the seller intentionally deprives himself of that which is his due as a human being. He deserves compensation for giving up a necessary good, for he will have to expend time and energy to reacquire this item. Moreover, there may be no guarantee he will be able to obtain a replacement. However, if the seller can give up a good that he does not really need, then the seller should not charge a higher price merely because the buyer is in dire need of this good.$^{61}$ In other words, a price does not qualify as fair simply because the market will bear it. The neediness of a particular buyer "confers no title on the seller to receive more than the common price" from the buyer. 62

The just person grasps the essential difference between these two cases. In the first, the seller gets a premium for treating himself unjustly in the process of treating the buyer justly; in the second, the seller seeks to exploit the neediness of the buyer. The same good may be changing hands in both cases. What is different is the individual circumstance of the seller. The just person price may well be higher in the first case than in the second, even though the same parties and same good is involved. Langholm is correct, then, to stress that, for Aquinas, the just person price manifests itself not only in the general market price but also in the individual contract price. ${ }^{63}$ Aquinas neatly reconciles two superficially contradictory possibilities: On the one hand, our evaluations of the worth of the good reflect our subjective assessment; yet, on the other hand, a just price exists (which is reflected in the common estimate) that is, for the individual buyer and seller, practically speaking, entirely objective. As Dempsey puts it, "My estimate of the worth of an object to me will be one of the factors determining the community estimate which will determine the just price. Yet that just price, resultant of many objective and subjective forces, once determined is for me a wholly objective fact." 64

Our praise of Aquinas's approach should not be taken to imply that it has no difficulties or limitations. As we noted earlier, Aquinas offers no general theory of efficient resource allocation, maximization of purchasing power, or comparative advantage. It is difficult to see how one could derive a comprehensive theory of exchange from his theory of the just price, given that Aquinas does not have a robust 
idea of relative exchange value. As Sewall has observed, the idea of exchange value comes to fruition only in a money economy in which parties routinely use exchange to make profit to be used to fulfill an expanding range of desires. ${ }^{65}$ In the medieval era, people did not exchange things to gain purchasing power. They more typically immediately consumed goods bought to meet their needs. The main focus of medieval exchange was on the simple utility of the acquired product to meet individual and familial needs, not the effect of the transaction on purchasing power per se.

Aquinas's treatment presupposes that people know their neighbors and are buying and selling in a local market. Today consumers and sellers, for the most part, operate in a global and largely anonymous market. Yet that, too, is changing as consumers are urged to buy local goods. Recent food quality scares have led Japanese supermarkets to post pictures of farmers above the goods they have grown. Japanese housewives want some sense of exactly who has produced the spinach and mushrooms. In addition, the practices discussed in the context of the medieval village likely pertain to isolated villages even today.

So, despite some serious limitations, the time has arrived to take seriously Aquinas's concept of the just person price. Even now we see economic disciplines like finance moving away from the idea that a firm's goal should be to maximize shareholder wealth and toward the idea that the goal of the corporation should be to create genuine, sustainable value truly benefiting shareholders, consumers and employees alike. ${ }^{66}$ In other words, all stakeholders deserve to be rendered their due-an idea highly reminiscent of Aquinas's theory of justice! If this rendered value is to be sustainable, then we will collectively need to rethink the idea that more is always better and that every desire deserves to be sated. Aquinas's thinking can promote such a reassessment.

In addition, Aquinas's theory implies that for some products, there is and can be no just price. Some products and services are so harmful to individuals in the community that they should not be produced or consumed in the first place. As we come to grips with the reality of global warming and the dangers of certain forms of energy production, it seems likely that we will increasingly be asking ourselves: Is this a product that should exist, even if it can be produced in a manner which yields normal profits when sold at an affordable price? Modern economic theory offers little to advance this issue beyond the Thomistic approach. Dempsey beautifully summarizes the power and continuing worth of Aquinas's just person approach to the fair price:

The exchange of the increased product made possible by the diversification of [social functions] must take place at a fair price, else the commonwealth will suffer. In an organism, the diminution of function in one organ means a diminution of function in all. When society permits transactions at other than just prices, it is cutting off its nose to spite its face.... In such an organization of society, the tension of class conflict, which is unnatural and philosophically as well as practically inhuman, is relieved because men, on a basis of what they are, stand united according to what they do, not divided according to what they have or have not. There is achieved, not a sterile and futile socialization of goods, but a natural and fruitful socialization of men. ${ }^{67}$ 


\section{NOTES}

We would like to thank the three anonymous reviewers who gave us extensive and very helpful comments on an earlier version of this article. Special thanks as well to members of the University of St. Thomas, Houston, Texas, brown bag business school group and to Dr. Alan Strudler and Dr. Farhad Rassekh of the University of Hartford for insightful comments on an earlier draft.

1. "A survey of the standard works on the just price ... will show that there has been an invariable neglect of the period from the Church Fathers to Thomas Aquinas." Baldwin, "The Medieval Theories of the Just Price," 9.

2. Others have noted that interpretations divide roughly into these two camps. See, e.g., McGee, "Thomas Aquinas"; Hamouda and Price, "The Justice of the Just Price," 191-92. See also Hollander, "On the Interpretation of the Just Price."

3. As we note later in the paper, it is crucial to keep in mind that Aquinas does not distinguish in a hard and fast way between the community good and the goodness of individual exchanges. On the contrary, he argues explicitly that being fair and just in exchanges is one of the primary ways in which we individually promote the common good on a daily basis.

4. For short time periods, the just price may fall below the costs of the representative firm. Indeed, as we shall argue later, for needy buyers, the just price may fall below cost for an extended period. This practice of varying the price among buyers involves what we today would term "price discrimination" but with a purpose quite different from the goal of profit maximization.

5. Maurer, About Beauty, passim. Maurer shows how St. Thomas certainly does have a theory of beauty, but this theory appears refracted, as it were, through Thomas's concern about being and Christian values. In a similar way, Aquinas does have a consistent theory of the just price, although he does not break out his thoughts in a separate section or volume devoted to the just price.

6. Jevons, The Theory of Political Economy.

7. Walras, Elements of Pure Economics.

8. Aquinas, SSII-II. 58, 2. We refer to the Summa Theologica as SS; "II-II, 58, 2" means second volume, second part, question 58 , article 2 .

9. Aquinas, SSII-II, 58, 2 and 3.

10. Aquinas, SSII-II, 58, 11.

11. Aristotle, Nicomachean Ethics, Book V, chap. 1, quoted by Aquinas at Aquinas, SSII-I, 66, 4.

12. Aristotle, Nicomachean Ethics, Book V, chap. 1, quoted by Aquinas at Aquinas, SSII-I, 66, 4.

13. Aristotle, Nicomachean Ethics, Book II, chap. 9, 1109b20-23. It is perfectly consistent with his "just person price" approach that Aquinas does not offer a general theory of the just price. He suggests elements of a just price by working through specific examples, which is exactly the approach one would expect him to take given that a just person always arrives at judgment in light of concrete particulars.

14. Aquinas, SSII-I, 2, 1.

15. This point has been noted by many, including Zwolinski, "Dialogue on Price-Gouging."

16. See Zwolinski's defense of what others would term "price-gouging" in Zwolinski, "Dialogue on Price-Gouging," passim.

17. While such an exchange price may in the short run deviate from the perfect competitor's long-run price, it is understood to occupy a point on the path towards this long-run price (which we offer as the neoclassical counterpart of the just price) and, indeed, to provide signals that contribute to the system's movement toward the perfect competitor's long-run price. In that respect, even a higher than usual exchange price would be considered by many neoclassicists as implicitly just.

18. Aquinas, SSII-II, 77, 1.

19. Some neoclassical economists would argue that gouging can be beneficial by functioning as a resource allocation mechanism. The gouger makes supernormal profits. Other sellers, seeing the huge profits to be made, will bring needed resources to the market and in the process eventually cause prices to fall.

20. Meng, "What Profits for a Man to Gain," 8. We agree with Meng in seeing Aquinas as arguing for a just person price, but he is more inclined than we to equate the just price with the market price. We work through a variety of specific cases and elaborate the idea of a just person price more fully, and less confusingly, than Meng does. Meng unpacks the just price idea using the natural law tradition employing quotes from modern authors and few references to Aquinas himself; this approach does not bring out the nuances of a just person price as rooted in neighborly exchanges among transactors who are sensitive to each other's 
needs. Instead, Meng grounds the justice of an act in conformity to natural law, a move that is somewhat dubious insofar as Aquinas (in his discussion of exchange) makes the act of rendering to each his or her due, not the natural law, the primary good. In addition, unlike Meng, we attempt to defend Aquinas's view by carefully contrasting it with neoclassical thinking. In his short paper, Meng does not identify the possible merits and limitations of a just person price approach.

21. Exchange for the sake of profit is "justly deserving of blame, because, considered in itself, it satisfies the greed for gain, which knows no limit and tends to infinity. Hence trading, considered in itself, has a certain debasement attaching thereto, in so far as, by its very nature, it does not imply a virtuous or necessary end. Nevertheless gain which is the end of trading, though not implying, by its nature, anything virtuous or necessary, does not, in itself, connote anything sinful or contrary to virtue: wherefore nothing prevents gain from being directed to some necessary or even virtuous end, and thus trading becomes lawful. Thus, for instance, a man may intend the moderate gain which he seeks to acquire by trading for the upkeep of his household, or for the assistance of the needy: or again, a man may take to trade for some public advantage, for instance, lest his country lack the necessaries of life, and seek gain, not as an end, but as payment for his labor." Aquinas, SSII-II, 77, 4.

22. Zwolinski, "Dialogue on Price-Gouging," passim.

23. Snyder, "What's the Matter with Price-Gouging?"

24. Aquinas, Comment, In Decem Libros Ethicorum Expositio, book 5, lectures 7, 8.

25. Aquinas, SSII-II, 77, 1.

26. Aquinas, SSII-II, 77, 4. Aquinas's concept of "profit" in this context incorporates elements of compensation for labor and interest as well.

27. Aquinas, SSII-II , 44, 7

28. Aquinas quoted in Monroe, Early Economic Thought, 63.

29. Aquinas, SSII-II, 183, 1.

30. Roover thus sardonically caricatures those who think that Aquinas and his fellow medievalists had no understanding of the market. Roover, "The Concept of the Just Price," 418.

31. Private property is good "because every man is more careful to procure what is for himself alone than that which is common to many or to all: since each one would shirk the labor and leave to another that which concerns the community, as happens where there is a great number of servants. Secondly, because human affairs are conducted in more orderly fashion if each man is charged with taking care of some particular thing himself, whereas there would be confusion if everyone had to look after any one thing indeterminately." Aquinas, SSII-II, 66, 2.

32. "And as to artificial wealth, it is not sought save for the sake of natural wealth; since man would not seek it except because, by its means, he procures for himself the necessaries of life. Consequently much less can [artificial wealth] be considered in the light of the last end. Therefore it is impossible for happiness, which is the last end of man, to consist in wealth." Aquinas, SSII-I, 2, 1.

33. Roover, "Monopoly Theory Prior to Adam Smith."

34. Schumpeter, Capitalism, Socialism and Democracy, 81-90.

35. See Roover, "The Concept of the Just Price," for a discussion of these and other authors' views of the just price.

36. Roover, "Monopoly Theory Prior to Adam Smith," 502-04, 523.

37. Ibid.

38. "Prudence consists in a right estimate about matters of action. Now a right estimate or opinion is acquired in two ways, both in practical and in speculative matters, first by discovering it oneself, secondly by learning it from others." Aquinas, SSII, 49, 4. See also McMahon, "A Reaction to Vogel's 'The Ethical Roots of Business.",

39. Dempsey, "Just Price in a Functional Economy," 482. Aquinas allows the seller to add the amount he planned to donate to charity as a cost of production. For evidence on this point, see Hamouda and Price, "The Justice of the Just Price," 193.

40. "Now human law is framed for a number of human beings, the majority of whom are not perfect in virtue. Wherefore human laws do not forbid all vices, from which the virtuous abstain, but only the more grievous vices, from which it is possible for the majority to abstain; and chiefly those that are to the hurt of others, without the prohibition of which human society could not be maintained: thus human law prohibits murder, theft and such like." Aquinas, SSII-I, 96, 2.

41. Aquinas, Of God and His Creatures, 3, 128. 
42. Aquinas, SSII-II, 40, 2.

43. Aquinas quoted in Dempsey, "Just Price," 479.

44. Aquinas, Quaestiones Quodlibetales, Quodlibetum 7 um, question 7, article 17.

45. Aquinas quoted in Dempsey, "Just Price," 480.

46. Aquinas, In Decem Libros Ethicorum, book 5, lecture 9.

47. Ibid.

48. Johnson, "Just Price in an Unjust World," 168.

49. Schumpeter, A History of Economic Analysis, 911.

50. Our discussion here incorporates the concept of diminishing marginal utility.

51. Schumpeter, in a critical exposition, asserts that the neoclassical entrepreneur would be "forced to strain every nerve in order to maximize output and to minimize costs" and thereby achieve a "remarkable absence of some of the major sources of social waste." Schumpeter, Capitalism, Socialism and Democracy, 78.

52. Zwolinsky, "Dialogue on Price-Gouging."

53. Aquinas, SSII-II, 66. Aquinas goes on to argue that extreme need even legitimates theft of another's property: "[I]f the need be so manifest and urgent, that it is evident that the present need must be remedied by whatever means be at hand (for instance when a person is in some imminent danger, and there is no other possible remedy), then it is lawful for a man to succor his own need by means of another's property, by taking it either openly or secretly." Aquinas, SSII-II, 66, 7. Aquinas's solution to feeding the poor somewhat resembles the neo-conservative approach. Aquinas never recommends price controls to help the poor. His solution is to have the community feed them for free (i.e., to set an exchange price of zero).

54. Neoclassical economists would recommend direct subsidies to the poor through mechanisms such as a negative income tax rather than setting the price below equilibrium. In addition to causing product shortages, setting a price below its equilibrium value interferes with its signaling function. The equilibrium market price of a product indicates its relative scarcity or abundance. Forcing the market price to deviate from this value would send erroneous information to potential buyers and sellers. Instead of distorting prices through subsidies or price controls, neoclassicists prefer simply to give the poor money so that they will not starve.

55. Aquinas, SSII-II, 77, 1.

56. Aquinas, SSII-II, 77, 1.

57. Aquinas, SSII-II, 77, 3 .

58. "But if any of the foregoing defects be in the thing sold, and he knows nothing about this, the seller does not $\sin$, because he does that which is unjust materially, nor is his deed unjust. . . Nevertheless he is bound to compensate the buyer, when the defect comes to his knowledge. Moreover what has been said of the seller applies equally to the buyer. For sometimes it happens that the seller thinks his goods to be specifically of lower value, as when a man sells gold instead of copper, and then if the buyer be aware of this, he buys it unjustly and is bound to restitution: and the same applies to a defect in quantity as to a defect in quality.” Aquinas, SSII-II, 77, 3.

59. Ibid. Augustine himself goes on to say, "We have known people from humanitarian motives to have sold cheaply to their fellow citizens grain for which they had paid a high price." Augustine quoted in Dempsey, "Just Price," 475. The neoclassicist might respond that, at the negotiated exchange price, the book does get to the market and ends up in the hands of the person who derives the greater utility from owning the book.

60. Here again we sees the difference between a Thomist and neo-classical approach. If a good represents one thing to one seller and something else to other sellers, we no longer have a homogenous product. Homogeneity of products is essential to perfect competition. Otherwise stated, under perfect competition there can be only price, for everyone knows the market price. Consequently, no one would pay more or sell for less than that market price.

61. Aquinas, SSII-II, 77, 1.

62. Dempsey, "Ability to Pay," 358. Dempsey shows that all of the major economists within the scholastic tradition-Dominic Soto, Leonard Lessius, John Cardinal de Lugo, and Louis Molina—agreed that, for Aquinas, the price will not be just if the seller attempts to exploit the neediness of a single buyer by charging more than the common estimate.

63. Langholm, Economics in Medieval Schools, passim. Neoclassical economics does not have much to say about the individually contracted price. 
64. Dempsey, "Just Price," 476. Contrast Dempsey's position with McGee's claim that "value cannot be both objective and subjective at the same time." McGee, "Thomas Aquinas," 479.

65. Sewall, The Theory of Value before Adam Smith, 30-31.

66. See, e.g., the current finance textbook by Eugene F. Brigham and Michael C. Ehrhardt, Financial Management, 7-11; 517-51.

67. Dempsey, "Just Price," 486.

\section{REFERENCES}

Alexander, Larry, and Maimon Schwarzschild. "Subversive Thoughts on Freedom and the Common Good," Michigan Law Review 97(6) (May 1999): 1813-27.

Aquinas, Thomas. In Decem Libros Ethicorum Expositio, ed. R. M. Spiazzi. Turin: Marietti, 1964.

. Of God and His Creatures, trans. J. Rickaby. London: Burns and Oates, 1905.

. Quaestiones Quodlibetales, trans. Sandra Edwards. Toronto: Pontifical Institute of Mediaeval Studies, 1983.

. The Summa Theologica, trans. Fathers of the English Dominican Province, 2nd rev. ed. London: Burns, Oates \& Washbourne, 1912-1936.

Ashley, William J. "Justum Pretium," in Palgrave's Dictionary of Political Economy, vol. 2 (1926), 500-01.

Baldwin, John W. "The Medieval Theories of the Just Price: Romanists, Canonists, and Theologians in the Twelfth and Thirteenth Centuries," Transactions of the American Philosophical Society 49(4) (1959).

. Review of Odd Langholm's Economics in Medieval Schools, Speculum 69(1) (January 1994): 200-03.

Barath, Desire. "The Just Price and the Costs of Production According to St. Thomas Aquinas," New Scholasticism 34 (October 1960): 413-30. . "Value, Price and St. Thomas." The Thomist 25 (1960): 325-81.

Brigham, Eugene F., and Michael C. Ehrhardt. Financial Management. Mason, Ohio: Thomson Southwestern, 2008.

Chafuen, Alejandro A. Christians for Freedom: Late-Scholastic Economics. San Francisco, Calif.: Ignatius Press, 1986.

. Faith and Liberty: The Economic Thought of the Late Scholastics. Lanham, Md.: Lexington Books, 2003.

Dempsey, Bernard W. “Ability to Pay,” Quarterly Journal of Economics 60(3) (May 1946): 351-64.

"Just Price in a Functional Economy," American Economic Review 25(3) (September 1935): 471-86.

Dempsey, Michael T. "What Bearing, If Any, Does the Christian Doctrine of Providence Have Upon the Operation of the Market Economy?," Journal of Markets \& Morality 8(2) (Fall 2005): 481-92.

Dougherty, Richard J. "Catholicism and the Economy: Augustine and Aquinas on Property Ownership,” Journal of Markets and Morality 6(2) (Fall 2003): 479-95. 
Epstein, Richard A. Principles for a Free Society: Reconciling Individual Liberty with the Common Good. New York: Basic Books, 2002.

Finkelstein, Joseph, and Alfred L. Thimm. Economists and Society: The Development of Economic Thought from Aquinas to Keynes. New York: Harper and Row, 1973.

Gershfield, Edward M. "Business Regulation and Price Control in Talmudic Economics," International Journal of Social Economics 13(9) (1986): 45-52.

Gordon, Barry J. "Aristotle and the Development of Value Theory," The Quarterly of Journal of Economics 78(1) (February 1964): 115-28.

Hägg, Claes. "Just Price and Equal Opportunity," Journal of Business Ethics 2 (1983): 269-72.

Hamouda, Omar. F., and Betsy B. Price. "The Justice of the Just Price," The European Journal of the History of Economic Thought 4(2) (Summer 1997): 191-216.

Hollander, Samuel. "On the Interpretation of the Just Price," Kyklos 8(4) (1965): 615-34.

Jevons, W. Stanley. The Theory of Political Economy, 4th ed. London: Macmillan, 1911.

Johnson, Edgar A. J. "Just Price in an Unjust World," International Journal of Ethics 48 (1938): 165-81.

Johnston, Joseph F., Jr. "Natural Law and the Fiduciary Duties of Business Managers," Journal of Markets \& Morality 8(1) (Spring 2005): 27-51.

Kaula, Rudolf. Theory of the Just Price: A Historical and Critical Study of the Problem of Economic Value, trans. Robert D. Hogg. London: George Allen and Unwin Ltd., 1940.

Langholm, Odd. "Economic Freedom in Scholastic Thought," History of Political Economy 14 (1982): 260-83.

Economics in Medieval Schools: Wealth, Exchange, Value, Money and Usury according to the Paris Theological Tradition, 1200-1350. Leiden: E. J. Brill, 1992.

"Monopoly and Market Irregularities in Medieval Economic Thought: Traditions and Texts to A.D. 1500," Journal of the History of Economic Thought 28(4) (December 2006): 395-411.

Price and Value in the Aristotelian Tradition: A Study in Scholastic Economic Sources. Oslo: Universitetsforlaget, 1979.

Lowry, S., and B. Gordon, eds. Ancient and Medieval Economic Ideas and Social Justice. Leiden: Brill Academic Publishers, 1998.

Lynch, Tony, and Adrian Walsh. "The Very Idea of Justice in Pricing," Business and Professional Ethics Journal 28(3/4) (Fall/Winter 2002): 5-28.

Maurer, Armand. About Beauty: A Thomistic Interpretation. Houston: Center for Thomistic Studies, 2011.

McGee, Robert W. "Thomas Aquinas: A Pioneer in the Field of Law and Economics," Western State University Law Review 18(1) (Fall 1990): 471-83.

McKinnon, Thomas R. "Just Price in Medieval Europe: Underlying Economic Factors," International Advances in Economic Research 6(3) (August 2000): 592-93.

McMahon, Thomas F. "A Reaction to Vogel's 'The Ethical Roots of Business," Business Ethics Quarterly 1(2) (April 1991): 211-22. 
Meng, Jude Chua Soo. "What Profits for a Man to Gain: Just (the) Price (of the Soul)," Journal of Markets \& Morality 8(1) (Spring 2005): 7-26.

Michel, Christian. "What Is a 'Just Price'?,' Journal of Markets \& Morality 2(2) (Fall 1999): 182-96.

Monroe, Arthur Eli, ed. Early Economic Thought. Cambridge, Mass.: Harvard University Press, 1930.

Piedra, Alberto M. Natural Law: The Foundation of an Orderly Economic System. Lanham, Md.: Lexington Books, 2004.

Roover, Raymond de. "The Concept of the Just Price: Theory and Economic Policy," Journal of Economic History 18 (December 1958): 418-38.

. "Monopoly Theory Prior to Adam Smith: A Revision," The Quarterly Journal of Economics 65(4) (November 1951): 492-524.

La Pensée Economique des Scholastiques. Doctrines et Méthodes. Montreal: Institut d'Etudes Médiévales, 1971.

Schumpeter, Joseph A. Capitalism, Socialism and Democracy. New York: Harper \& Bros., 1950.

. A History of Economic Analysis. New York: Oxford University Press, 1954.

Sewall, Hannah Robie. The Theory of Value before Adam Smith. New York: American Economic Association, 1901.

Snyder, Jeremy. "What's the Matter with Price-Gouging?," Business Ethics Quarterly 19(2) (April 2009): 275-93.

Walras, León. Elements of Pure Economics, trans. William Jaffe. Homewood, Ill.: Richard D. Irwin, 1954.

Walsh, Adrian. "The Morality of the Market and Medieval Schoolmen," Politics, Philosophy and Economics 3(2) (2004): 241-59.

Woelfel, B. LaSalle. Catholic Thought in Business and Economics. Austin, Tex.: St. Edwards University Press, 1959.

Wood, Diana. Medieval Economic Thought. Cambridge: Cambridge University Press, 2002.

Zwolinski, Matt. "Dialogue on Price-Gouging," Business Ethics Quarterly 19(2) (April 2009): 294-303. 